\title{
HasanuddinLawReview
}

\section{Broadening of the Concept of Obscenity in the Draft of Indonesian Penal Code}

\author{
Ali Rezky1, Oheo Kaimuddin Haris ${ }^{2}$ \\ ${ }^{1}$ Faculty of Law, Halu Oleo University, Indonesia, E-mail: alirizky76@gmail.com \\ ${ }^{2}$ Faculty of Law, Halu Oleo University, Indonesia, E-mail: oheo.haris@uho.ac.id
}

\begin{tabular}{l} 
ARTICLE INFO \\
\hline Keywords: \\
Criminal Law; Draft Penal \\
Code; Law Reform; \\
Obscenity \\
How to cite: \\
Rezky, A., and Haris, O.K. \\
(2018). "Broadening of the \\
Concept of Obscenity in the \\
Draft of Indonesian Penal \\
Code," Hasanuddin Law \\
Review, 4(2): 233-241 \\
DOI: \\
10.20956/halrev.v4i2.1402
\end{tabular}

\begin{abstract}
The reform of the Indonesian Penal Code (KUHP) is necessary to accommodate the noble values of Indonesian society. Therefore, Indonesian criminal law should reflect the basic principles, cultural values that live within the inner niches of Indonesian society as a living law. The inclusion of several forms of obscene acts that exist within the extended Draft Penal Code is a manifestation of the philosophical, sociological and juridical framework of the Indonesian society. The extension of the concept of obscenity in the Draft of Indonesian Penal Code is in accordance with the philosophy of the Indonesian nation that gives religious values a fundamental place Consequently, the expansion of the concept of obscenity in the Draft of Indonesia Penal Code can answer some of the problems faced by Indonesian citizens.
\end{abstract}

Copyright (C) 2018 HALREV. All rights reserved.

\section{Introduction}

The Indonesian Penal Code (KUHP) is believed to be about 72 years old as per the enactment of Law No. 1/1946 on the regulation of criminal law. However, if based on Wetbook van Strafrecht enacted by the Dutch Parliament on March 3, 1881', Indonesia's current Penal Code is approximately 137 years old. After such a long period of time, it can't be denied that the substance of some of the thoughts in the provisions contained in the Penal Code are no longer contextual with the condition of Indonesian society today. Therefore, the reform of criminal law is done partially to revise substances that are not in accordance with the condition of Indonesian society or to fill the legal void contained in the Penal Code. Hence, various laws and regulations have been enacted to make fragmented changes either through the amendments to the Penal Code or through a special criminal act which contains deviations from the principles the penal code and

1 Hiariej, E.O.S. (2014). Prinsip-Prinsip Hukum Pidana. Yogyakarta: Universitas Atma Jaya. p.19 
also in addition to the administrative penal law developed to utilize criminal sanctions in support of administrative law norms. ${ }^{2}$

Partial Criminal law reforms in the Penal Code can be seen with the enactment of Law No. 20/1946 on Criminal Cases, Law No. 73/1958 which added several articles such as Article 52a, Article 142a and Article 154a, Law No. 1/1960 which added the threat of punishment as set in articles 359, 360 and Article 188 of the Penal Code, Law No. 7/1974 which sets criminal act of gambling as a crime and its punishment, Law No. 27/1999 which adds provisions related to state security, the Supreme Court Decision No. 02/2012 on the Adjustment of minor criminal offenses and the fines in the Penal Code. Reform of the Criminal Law relating to the Penal Code is not done by amending the Penal Code itself and by establishing special criminal legislation outside the Penal Code, for example, Law No. 31/1999 jo. Law No. 20/2001 on the Eradication of Corruption, Government Regulation in Lieu of Law No. 1/2002 jo. Law No. 15/2003 on Combating Terrorism, Law No. 21/2007 on Human Trafficking. Such a partial revision of the Penal Code aims to answer the problems arising from the legal vacuum contained in the Penal Code itself. The revision gives the impression that criminal law policies, especially those related to the Penal Code, are still concerned with the patchwork of the Penal Code itself. Therefore, to avoid such perception, the thorough reform of the material criminal law, especially the Indonesian Penal Code, thoroughly becomes a necessity in the Indonesian criminal law system.

According to Oemar senoadji, obscene acts and moral crimes are fundamental issues for criminal justice reform effort, especially in formulating the provisions concerning criminal acts of decency. ${ }^{3}$ So reform to make trick regulations on obscenity and related issues is very important so as to achieve legal certainty. Mary Harney highlighted that there is one justice, not exclusive compartment, called civil justice, criminal justice, social justice or economic justice justice" 4 . This paper examines the extension of the concept of obscenity in the Indonesian Draft Penal Code and the its difference with the Penal Code including ideas and philosophical, sociological and juridical principles of several articles relating to the expansion act of obscenity in the Draft Penal Code.

\section{Method}

Judging from its type, this research is normative legal research or library research, which focuses both on positive law norms in the form of laws and regulations and on library literature as the main data. Seeing from the nature, this research is a descriptive legal research that describes thoroughly the extension of the concept of obscenity in the Draft Penal Code (RKUHP) from theoretical, philosophical, sociological and juridical point of view. In order to provide a complete and clear picture, several approaches are used in conducting research such as the statute approach to examine laws and regulations related to the legal issue under study and to compare them with the Draft Penal Code, conceptual approach that is departing from the views and doctrines that developed in the science of law, especially criminal law. Method of data collection in normative legal research, conducted by literature study on legal materials i.e., primary, secondary and

2 Muladi. (2008), Pembaharuan Hukum Pidana Materiil Indonesia, (Paper), Seminar \& Kongres ASPEHUPIKI, Bandung, 16-18 March 2008.

3 See Draft of Indonesian Penal Code (RKUHP). (2015). Badan Pembinaan Hukum Nasional Kementrian Hukum dan Hak Asasi Manusia Republik Indonesia, p 239

4 Tumpa, H. (2015). Penerapan Konsep Rechtsvinding dan Rechtsschepping oleh Hakim dalam Memutus Suatu Perkara. Hasanuddin Law Review, 1(2), 126-138. doi: http://dx.doi.org/10.20956/halrev.v1n2.90. 
tertiary legal materials. These legal materials are then read and reviewed selectively to determine which legal substances are relevant to the context of this research on the extension of the concept of obscenity in the Draft Penal Code. All the collected legal materials were then inventoried, classified, processed and analyzed comprehensively so that conclusion can be drawn from the results of the analysis.

\section{Understanding of Obscenity}

The legislator did not give a clear account of the notion of obscenity thus leaving the judge to decide whether a particular act should or should not be regarded as obscene act. ${ }^{5}$ Topo Santoso defines obscene acts as are all acts that violate standards of respectability or morality, but also every act to/with one's body or the body of another person, which violates decency, including the act of intercourse. The Arrest Hooge Raad of 5 February 1912 (W. 9292) gives a definition of copulation as a sexual intercourse between a male and a female for procreation. Thus, the male must penetrate his genital into that of a female and leaves his semen therein. ${ }^{6}$ Similarly, R. Soesilo argues that obscene acts are all acts that violate decency or cruel acts, all of which are in the environment of sexual desire, for example: kisses, groping of the genitals or breasts. These acts also include sexual intercourse. ${ }^{7}$ What is referred to as obscene act, in this article, is any form of sexual activity determined as a criminal act in the Draft Penal Code, an extension of the existing Penal Code or in other words acts that are not yet contained in legislation.

\section{Criminalization Parameter}

The criminalization of an act must reflect the cultural values of the society so as to allow the legal product resulting from the criminalization process to be easily approved and obeyed by all the citizens. The Semarang Criminal law symposium specifies that in criminalizing an act, the state needs to pay attention to public attitudes and perceptions about the desirability of a particular act, by conducting research on issues related to technological progress and social change. In addition, in criminalizing an act the state should consider the following general criteria:

a) Whether the act is disliked or hated by the public because its harmful or can cause casualties.

b) Whether the cost of criminalizing is balanced with the expected outcome, meaning the cost of legislation, law enforcement and supervision, as well as the burden borne by victims of perpetrators and perpetrators, the crime itself must be balanced with the legal order to achieve. ${ }^{8}$

In line with Muladi, Bassiouni also argued that criminalization and decriminalization should be based on certain cultural factors that take into various factors, including:

a) The balance of the means used in relation to the results to be achieved;

b) Cost analysis of the results obtained in relation to the objectives sought;

5 Marpaung, L. (2008). Kejahatan Terhadap Kesusilaan dan Masalah Prevensinya. Jakarta: Sinar Grafika. p. 64.

6 Soesilo, R. (1956). Kitab Undang-Undang Hukum Pidana Serta Komentar-Komentarnya Lengkap Pasal Demi Pasal, Bogor: Politeia. p 181.

7 Eddyono, S.W. (2015). Catatan Terhadap Beberapa Ketentuan Dalam Rancangan KUHP. Jakarta: Institute for Criminal Justice Reform.

8 Soesilo, R. Ibid. 
c) Assessment or assessment of the objectives sought in relation to other priorities in the allocation of human resources; and

d) The social providers of criminalization and decriminalization relating to or viewed from their secondary effects.

\section{Basic Ideas and Urgency of the Extension of Obscene Acts in the Draft Penal Code}

The development of criminal law should pay attention to the national development goal, that is to create a just, equal and spiritual society based on Pancasila. In this connection, the use of criminal law aims to tackle crime and to affirm the action of the countermeasures itself, for the sake of the welfare and protection of the society. ${ }^{9}$ Sudarto strongly emphasized that the values of justice resulting from the use of criminal law should be based on Pancasila justice as the philosophical foundation of the state of Indonesia. Similarly, the criminalization of an act must place Pancasila as a very fundamental value.

In line with previous opinions, Senoadji argues that the determination of the content criminalization (matter) (moral decree) must be sourced and received strong backing from religious morals. The determination of moral decency should also be oriented to the national values of decency that have been agreed on together and also pay attention to the values of decency within the society because in the structure of Indonesian society, the value of national decency is also derived from religious values and values that live in society. ${ }^{10}$ In filling and directing the principles of decency, religious elements should play their part. This view merely considers the relationship between law and morals. The influence between the elements of religion on the law does not get any attention, especially in crimes against decency.

With regard to the Draft Penal Code extending the concept of obscene acts committed not only by persons of different sex but also persons of the same sex, whether or not in a marriage bond, it is part of the embodiment of the values contained in Pancasila especially the first precepts. As is commonly understood, the manifestation of divine values can be seen from the recognition of religions in Indonesia. Basically, obscene acts committed by persons of same/different sex have been criticized by all the recognized religions in Indonesia. Therefore, obscene act committed by people of same sex is often referred to as homosexuality and even though it is not set forth in the criminal law, it is blameworthy in the Indonesian society (mala in se). ${ }^{11}$

A comprehensive reform of the criminal law balances the relationship between the public interest, the interests of the state and those of individuals, it also balances the relationship between the protection of the perpetrator of a crime and the victim, the relationship between the elements of act and the forgiveness, legal certainty and justice, written law and living law within society, national values and universal values, human rights and basic human rights. These are the elements that must be realized. ${ }^{12}$ This pattern of balance is mentioned in the academic text of the Draft Penal Code as the

$9 \quad$ Ibid.

10 Arif, B.N. (2011). Bunga Rampai Kebijakan Hukum Pidana (Perkembangan Penyusunan Konsep KUHP Baru), Jakarta: Kencan Prenada Media Group, p. 251

11 Mala in se is an act which in itself is considered evil even though it is not regulated in the positive legal order of a country. as the comparison is mala prohibita that is an act considered evil if it has been arranged in a positive legal order of a country. See, Kelsen, H. (2010). Teori Umum Tentang Hukum Dan Negara. Bandung: Nusa Media. p. 75

12 Draft of Indonesian Penal Code (RKUHP). Op.Cit., p 165 
sociological basis of the Penal Code reform. Furthermore, the question as to what is the form of community's rejection of the acts referred to as criminal acts in the Penal Code, especially articles related to obscene acts needs to be considered.

The lack of equality of public perception about obscene acts set forth in the Penal Code often leads people to take action of eigenrechting or vigilance against the perpetrators of alleged acts of obscenity. This in turn can lead to legal uncertainty, which potentially disrupts and undermine national resilience. ${ }^{13}$ Vigilant action is a form of community rejection of the form of obscenity committed by individuals unbounded by marriage. Vigilant action is a form of "problem solving" conducted by society due to the impasse of the legal system that does not provide a solution to obscene acts. In addition, a number of such colonial legislations continue to apply today. Subsequently, after Indonesia declared independence on 17 August 1945, the Indonesian authorities began creating a national legal system based on Indonesian precepts of law and justice. ${ }^{14}$

The regulation of obscene acts in the current Penal Code can only entrap a person who commits an obscene act with or without marriage bond (Article 284 of the Penal Code). This article is very controversial because it contains a very strong liberal individual principle. Individual freedom is a highly esteem including freedom of contact during an unbound marriage. This formula is certainly very narrow and limits law enforcers in combating obscene acts in the community. Mudzakkir, when giving expert testimony in case before the Constitutional Court stated that:

What is actually forbidden by Article 284 of the Penal Code is the sexual intercourse of either a husband or a wife with another man or woman outside of the marriage. So essentially. This means that unless the individuals involved in a sexual intercourse are married, this article can't be applied". Mudzakkir's view is that the will of the legislator is addressed to men or women who are in a marriage bond. While act of obscenity can be perpetrated by anyone..$^{15}$

Taking into account the provisions governing the crime of adultery or obscene acts, it appears that although in general it has posed a threat to acts of sexual misconduct, the above provision does not fully criminalize all the perpetrators of obscenity. This is due to the weakness of the Penal Code as it gives them the opportunity to escape the law. ${ }^{16}$ The formulation of acts of obscenity contained in the present Penal Code, especially in relation to adultery requires an extension so as to cover various aspects and forms of obscene acts. It would be very reasonable, from the aspect of jurisdiction if the concept of obscenity set forth in the current Penal Code could be broadened in the Draft Penal Code.

13 Decision of the Indonesian Constitutional Court No. 46/PUU-XIV/2016, p. 36; Ulfah, Endang Nur. (2016). "Urgensi Pembaruan Kitab Undang-Undang Hukum Pidana: Analisis Kajian Perkara Nomor 46/PUU-XIV/2016". Indonesian Journal of Criminal Law Studies (IJCLS), 1(1), 72-86

14 Isra, Saldi, Ferdi F, Tegnan, H. (2017). "Rule of Law and Human Rights Challenges in South East Asia: A Case Study of Legal Pluralism in Indonesia", Hasanuddin Law Review, 3(2): 117-140.

15 The Indonesian Constitutional Court No. 46/PUU-XIV/2016, p. 88

16 Andriasari, D. (2011) "Studi Komparatif Tentang Zina Dalam Hukum Indonesia dan Hukum Turki", Syiar Hukum, 8(3), 266-279. 


\section{Some Forms of Expansion of Obscene Acts in the Draft Penal Code}

The formulation of the academic draft provides some suggestions regarding the acts to be included in criminal acts of indecency and some extensions that will become new criminal acts in the Draft Penal Code. Some of these crimes include:

a) Incest;

b) Sexual intercourse resulting in the pregnancy of an unmarried woman while the man concerned is not willing to marry her;

c) Perpetration of obscenity by adult persons of the same sex;

d) Sodomy;

e) Expansion of the meaning of rape. ${ }^{17}$

The following describes some form of acts of obscenity in the Draft Penal Code. Acts that requires further study is the form of obscenity perpetrated by two or more individuals on the basis of love or coercion. Such obscene acts include:

Firstly, incest is a sexual relationship among family members. Incest is often interpreted as a forbidden sexual relationship between close relatives. Previously the value of incest is based on norms of decency, customary and religion norms. Incest is set forth in Article 490 of the Draft Penal Code in the fourth section on adultery. If this Draft Penal Code is enacted then incest will become a crime. Here is the formulation of the article this in the Draft Penal Code which criminalizes incest:

1) Any person who has sexual intercourse with another person with whom they share family blood in a straight line or sideways until the third degree is punishable with a maximum imprisonment of 12 (twelve) years.

2) If the criminal act as referred to in paragraph (1) is committed by a man against a woman who is under 18 years of age or vice versa, the criminal offender shall be subject to a maximum imprisonment of 15 years.

3) Article 497 says that:

4) Any person committing an act of obscenity with their biological child, stepson, adopted child, or a child under their supervision entrusted to them shall be liable to a maximum imprisonment of 12 years.

5) Shall be sentenced to a maximum imprisonment of 12 (twelve) years:

a) an officer committing an act of obscenity with his/her subordinates or with a person entrusted or submitted to him for safekeeping; or

b) a physician, teacher, employee, caretaker, or officer of a penitentiary, state institution of work training, educational house, orphanage and, psychiatric hospital, or social institution performing committing act of obscenity with persons put under their responsibility.

Secondly, when looking closely at Article 485 which set forth sexual intercourse resulting in the pregnancy of the woman outside married, while the author of the pregnancy is unwilling to marry her, one may say that it targets men with and without marriage bonds. This article actually protects women' dignity.

1) The man who has intercourse with a woman with her consent because of he promise to be married her, but fails to deliver on that promise, shall be imprisoned for a maximum of 4 years or a maximum fine as much as the category III, as set forth in Article 484 paragraph (1).

17 Draft of Indonesian Penal Code (RKUHP). Op.Cit., p. 240 
2) In the case of a criminal offense resulting in pregnancy and the man is unwilling to marry or faces obstacles to do so shall be imprisoned for a maximum of 5 years or receive a category IV fine.

3) In the case of the woman the victim of the marriage promise, as referred to in paragraphs (1) and (2), the provisions referred to in Article 484 paragraph (1e) shall not apply. ${ }^{18}$

Thirdly, one of the most controversial articles is the article relating to the perpetration of obscene act by adults of the same sex ((homosexuals). The rejection of this article derives from people who promote the values of individualism and human rights. As far as we are concerned, what is problematic about this provision is the age limit of 18 years. The question is whether or not a 18 years old person who committed an act obscenity shall be convicted. It can be said that this article actually aimed to protect the minors from acts of obscenity. It does not criminalize same sex intercourse (homosexuals) in general. So according, we believe that there is an "irony" in the formulation of act obscenity in the Draft Penal Code because it criminalizes any form of acts of obscenity committed by married or unmarried people of different gender outside their marriage without any age restrictions. Only the law on homosexuality provide a 18 years old age limit. There still is void in the criminal system, even if the Draft Penal Code is adapted. The formulation of the criminalization of same-sex obscene acts is formulated in Article 495 of the Draft Penal Code as follows:

1) Any person committing an obscene act with other person of the same sex known or suspected to be under 18 years of age, shall be punished to a maximum imprisonment of 9 years.

2) The penalty shall by one third if the obscene act as referred to in paragraph (1) is done by means of oral sex or anal sex or the encounter of all forms of sex organs with genital conducted homosexually.

Fourthly, we believe that the concept of adultery that exists in the present Penal Code should be broadened. As argued earlier, the current Penal Code refers to adultery as a voluntary sexual intercourse between a married person and a person who is not their spouse. This definition of adultery is in contrast with that of the Draft Penal Code, which defines adultery as a voluntary sexual intercourse between not only married person and a person who is not their spouse but also between unmarried persons. Adultery is set forth in the Draft Penal Code in Article 484 which say:

1) Adultery is sentenced with a maximum imprisonment of 5 years:

a) a man in a marital relationship has intercourse with a woman who is not his spouse;

b) a woman in a marital relationship has sexual intercourse with a man who is not her husband;

c) a man who is not in a marital relationship has intercourse with a woman who is in a marriage bond;

d) a woman who is not in a marital relationship intercourse with a male hwho is known to have in a marriage bond; or

e) men and women each of whom is not bound in a legitimate marriage to have sexual intercourse.

$18 \quad$ Ibid. 
2) There shall be no prosecution unless a complaint is raised by a husband/wife or a third party directly affected by the act of adultery, as mentioned in article 1 .

3) For complaints as referred to in paragraph 2, the provisions of Article 26, Article 27, and Article 29 shall not apply.

4) Complaints may be withdrawn while the court hearing has not yet begun. ${ }^{19}$

\section{Conclusion}

In light of some criminalization parameters put forward by the criminal law experts discussed above, it can be concluded that obscene acts that exist in the Penal Code should be broadened to criminalize other actions related to obscenity. Some forms of obscene acts in the Draft Penal Code have met the criteria or parameter of criminalization as expressed by criminal law experts. The extension of the concept of obscenity in the Draft of Indonesian Penal Code is in accordance with the philosophy of the Indonesian nation (Pancasila) that gives religious values a fundamental place despite the fact that some form of obscene acts in the Draft Penal Code contradict some religious values adopted in Indonesia. If viewed from a sociological point of view, the occurrence of vigilance is a form of public resentment towards obscene acts that occur in the society, in order to avoid such problem, it is important to criminalize certain acts related to obscenity in Indonesian criminal law.

Juridically, some acts of obscenity (incest, sexual intercourse resulting in pregnancy of woman while the author of the pregnancy is unwilling to marry her, obscene acts committed by people of the same sex and adultery) are not accommodated by the current criminal law system, especially the Penal Code and other legislation. Such void should be filled and accommodated by the Draft Penal Code. This does not mean that the Draft Penal Code, especially part related to acts of obscenity, is without deficiency. This deficiency includes obscene acts between persons of the same sex because its article 495 only sets the age limit of 18 years for the offender. The lawmakers should not set age restrictions for perpetrators of same-sex obscene acts because these acts are deemed very disgraceful by the public.

\section{References}

Journal Articles:

Andriasari, D. (2011) "Studi Komparatif Tentang Zina Dalam Hukum Indonesia dan Hukum Turki", Syiar Hukum, 8(3), 266-279.

Isra, Saldi, Ferdi F, Tegnan, H. (2017). "Rule of Law and Human Rights Challenges in South East Asia: A Case Study of Legal Pluralism in Indonesia", Hasanuddin Law Review, 3(2): 117-140.

Tumpa, H. (2015). Penerapan Konsep Rechtsvinding dan Rechtsschepping oleh Hakim dalam Memutus Suatu Perkara. Hasanuddin Law Review, 1(2), 126-138. doi: http://dx.doi.org/10.20956/halrev.v1n2.90.

Ulfah, E.N. (2016). “Urgensi Pembaruan Kitab Undang-Undang Hukum Pidana: Analisis Kajian Perkara Nomor 46/PUU-XIV/2016". Indonesian Journal of Criminal Law Studies (IJCLS), 1(1), 72-86.

19 Ibid. 
Books:

Arif, B.N. (2011). Bunga Rampai Kebijakan Hukum Pidana (Perkembangan Penyusunan Konsep KUHP Baru), Jakarta: Kencan Prenada Media Group.

Draft of Indonesian Penal Code (RKUHP). (2015). Badan Pembinaan Hukum Nasional Kementrian Hukum dan Hak Asasi Manusia Republik Indonesia.

Eddyono, S.W. (2015). Catatan Terhadap Beberapa Ketentuan Dalam Rancangan KUHP. Jakarta: Institute for Criminal Justice Reform.

Hiariej, E.O.S. (2014). Prinsip-Prinsip Hukum Pidana. Yogyakarta: Universitas Atma Jaya. Kelsen, H. (2010). Teori Umum Tentang Hukum Dan Negara. Bandung: Nusa Media.

Marpaung, L. (2008). Kejahatan Terhadap Kesusilaan dan Masalah Prevensinya. Jakarta: Sinar Grafika.

Muladi. (2008), Pembaharuan Hukum Pidana Materiil Indonesia, (Paper), Seminar \& Kongres ASPEHUPIKI, Bandung, 16-18 March 2008.

Soesilo, R. (1956). Kitab Undang-Undang Hukum Pidana Serta Komentar-Komentarnya Lengkap Pasal Demi Pasal, Bogor: Politeia.

Legal Document

Law No. 1 of 1946 on the Indonesian Penal Code.

Decision of the Indonesian Constitutional Court No. 46/PUU-XIV/2016

Draft of Indonesian Penal Code (RKUHP). (2015). Badan Pembinaan Hukum Nasional Kementrian Hukum dan Hak Asasi Manusia Republik Indonesia 